\title{
生活行為を想定した室内照度・色温度の好ましさに関する模型実験 THE PREFERENCE OF THE INDOOR ILLUMINANCE AND COLOR TEMPERATURE: SCALE MODEL EXPERIMENT ASSUMING DAILY ACTIVITY
}

\author{
大井尚行*，笠尾 円**，高橋浩伸*** \\ Naoyuki OI, Madoka KASAO and Hironobu TAKAHASHI
}

\begin{abstract}
This paper aims to show the preferred combinations of illuminance and color temperature under various daily activities in residential houses.

Subjective experiments were carried out using scale models illuminated by RGB fluorescent lamps with the dimmer. "Preference", "Brightness", and "Naturalness of color appearance" were evaluated as the scenes of "Relaxing", "Getting together", "Dining", "Cooking", "Learning", and "Resting (before retiring)". 25 combinations which consist of 5 illuminances $(50 \mathrm{~lx}, 100 \mathrm{~lx}, 200 \mathrm{~lx}, 400 \mathrm{~lx}, 800 \mathrm{~lx})$ and 5 color temperatures $(3000 \mathrm{~K}, 3500 \mathrm{~K}, 4200 \mathrm{~K}, 5000 \mathrm{~K}, 6500 \mathrm{~K})$ were investigated. Preferred combinations of illuminance and color temperature vary according to the activity.

The results show that the traditional Kruithof's curve is not necessarily effective under various scenes in the residential houses.
\end{abstract}

Keywords : Daily Activity, Illuminance, Color temperature, Preference, Scale Model 生活行為, 照度, 色温度, 好ましさ, 模型

\section{1.はじめに}

\section{1 室内の照度・色温度に関する既往研究}

室内空間の雾囲気や演出を考える場合、照明光の照度や色温度は 重要な要因となり、目的に応じて照度・色温度を選択することが望 まれる。また、好ましい光の色温度は照度と関係があるとされてお り、Kruithofの「光源の色温度によって快適な照度の上限およで下 限が変化する」 ${ }^{1)}$ という考え方が広く用いられてきた ${ }^{2)}$ 。低照度では 色温度の低い温かい光が、高照度では色温度の高い冷たい光が好ま れるという関係である。しかし、Kruithofの実験には以下に示寸よ うないくつかの問題点が指摘されている。

1. 実験で用いられた光源が色温度の低い領域では電球、色温度の高 い領域では演色性の低い蛍光ランプが使用されており、色温度だ

けでなく、演色性、光の拡散性も同時に変化している。

2.色順応の影響が考虑されているのか否か述べられていない。

3. 何が快適さの判断基準になるのかという観察条件が明らかで㐫な い。

これまでに、気温 ${ }^{3)} 、$ 周囲色彩 ${ }^{4)} 、$ 照明配置5)、作業行為 ${ }^{5), 61}$ ，室内 空間共有者の有無》などの条件制御をおこなった既往研究:こより Kruithofの快適領域の照明条件が必ずしも不快領域の照明条件之り
も快適にならない場合があり得ることが指摘されている。

行為との関係を扱った研究として、中村らう燳度・色温度が住宅 のリビングの照明の雾囲気の好ましさに及ぼす影響を明らかにする ことを目的とし、実験設備に実験用リビングルームと調色照明シス テムを用いて実験を行っている。被験者は、「だんらん」と「くつ ろぎ」を想定して基準の照明シーンに対するテストの照明シーンの 「好き一嫌い」を7段階尺度で評価した。被験者は20歳代〜50歳代の 男女6名（うち女性2名）である。

その結果から、この実験の条件である照度100 8001x、色温度 3000 〜5600Kの範囲において、中村は「だんらん」と「くつろぎ」では各 生活行為で希望する雾囲気が異なるために所要照度も異なるのでは ないか、と考察を述べている。また、Kruithofの実験結果との比較 を行い、だんらんの場合はKruithof と中村らの実験結果は比較的よ く似ているが、くつろぎの場合はKruithofの快適領域内であっても、 8001xの照明状態がそれほど好まれていないことから、Kruithofの結 果と若干異なることを指摘している。

\section{2 本研究の目的}

本研究は、調色照明器具と縮尺模型を用いた印象評価実験を通し て、住宅で想定される生活行為の下での照明光の照度・色温度の組
* 九州大学大学院芸術工学研究院 助教授. 工博

** 九州大学大学院芸術工学府 修士課程

*** 九州大学大学院芸術工学研究院 COE 学術研究員・博士 (工学)
Assoc. Prof., Faculty of Design, Kyushu University, Dr. Eng.

Master's Program, Graduate School of Design, Kyushu University

COE Research Fellow, Faculty of Design, Kyushu University, Dr. Eng. 
み合わせと照明の好ましさの関係を明らかにすることを目的として いる。そのために模型実験を行い、中村らの実駼結果引の傾向を確か め、さらに通常住宅で行うと考えられる4つの行為を加えた計 $6 つ の$ 生活行為ごとに、好ましい照度・色温度の範囲の組み合わせを見い だす。

\section{2. 実験用照明装置の特性}

\section{1 実験用照明装置概要}

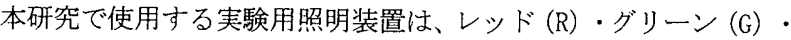
ブルー（B）の3本のコンパクトカラー蛍光ランプ（松下電工、 FPL36ER, FPL36EG, FPL36EB、各36W）を装着した乳白パネル付調色照 明器具である。器具としては、ホワイト (W) の蛍光ランプも併用す る仕様だが、光量よりも色温度可変範囲を優先して、ホワイトは使 用しない。調光はパソコンからの制御電圧により行う9)。

\section{2 RGB巣光ランプ各単色点灯時の照度 · 色度の変化}

パソコンからの制御電圧により調光した照明光の照度およびxy色 度を色彩照度計（MINOLTA CL-200）で測定した。図1に測定装置と測 定に用いた測定機の位置を示す。まず、基本となる $\mathrm{R} \cdot \mathrm{G} ・ \mathrm{~B}$ 蛍光ラン プの特性を把握するために、各単色点灯時の照度および色度を測定 する。各単色光点灯後、照度・色度が安定したところで制御電圧を 最大值(10V)から1Vずつ減少させるたびに色度および色温度を測定 する。

表 1 に各蛍光ランプの色度值と測定条件での照度の最大・最小值 を示す。制御電圧の減少にほぼ比例して照度は減少する。各単色光 点灯時の色度は制御電圧による変化は少なく、ほぼ安定している。

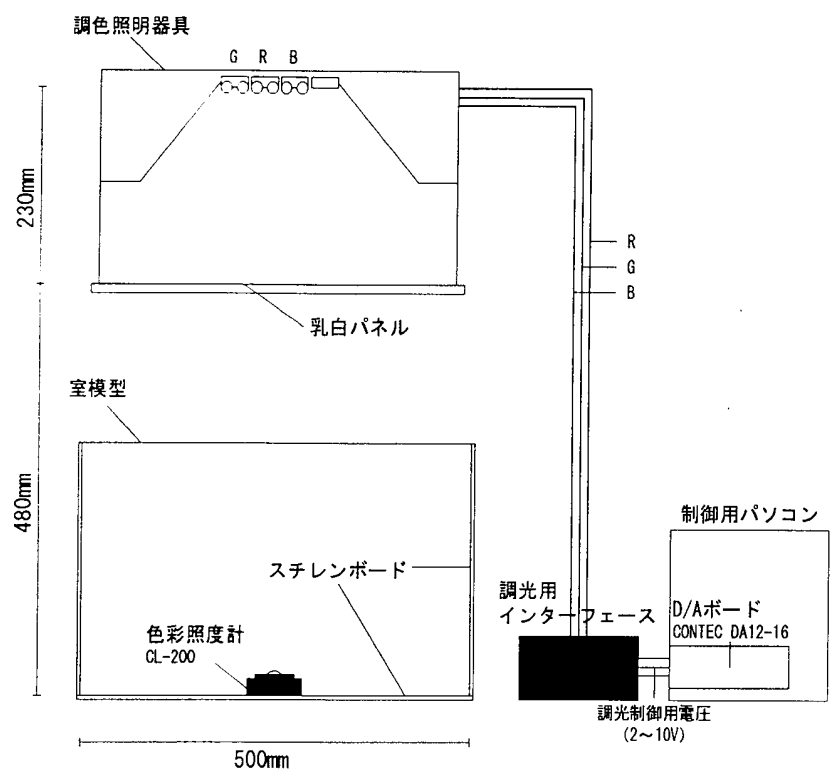

図 1 調色照明装置と模型（測定用）

表 1 RGB 蛍光ランプの色度と最大・最小照度

\begin{tabular}{|c|c|c|c|c|}
\hline & \multicolumn{2}{|c|}{ 色度値 } & \multicolumn{2}{c|}{ 照度[1x] } \\
\hline & $x$ & $y$ & $\max$ & $\min$ \\
\hline$R$ & 0.60 & 0.33 & 1474 & 8.7 \\
\hline$G$ & 0.34 & 0.54 & 2444 & 28.9 \\
\hline$B$ & 0.15 & 0.09 & 580 & 2.9 \\
\hline
\end{tabular}

\section{3 相関色温度の再現に必要な制御電圧条件の測定}

本照明器具において一般的に用いられる蛍光ランプの相関色温度 论下 色温度) $3000 \mathrm{~K}$ (電球色)、3500K（温白色）、4200K (白色)、 $5000 \mathrm{~K}$ (昼白色)、6500K（昼光色）の光色を黒体軌跡上に再現できる ように、制御電圧条件の調整を行った。一定照度で色温度を変化さ サるために、まず照度を10001x、20001x、30001xに設定し、2Vおき に測定したデータから色温度の目標值に近い部分を抜き出す。そし 一更に細かくR・Gを1Vおきに、Bを0.5Vおきに変化させ、色度および 照度を計測する。ここで得られたデータをもとに照度・色温度再現 の目標値に必要な制御電圧を予測し調整を行う。

結果を図2に示す。この模型において照度10001x、20001x、30001x ジは、ほぼ黒体軌跡に沿った色温度を再現することが可能である。

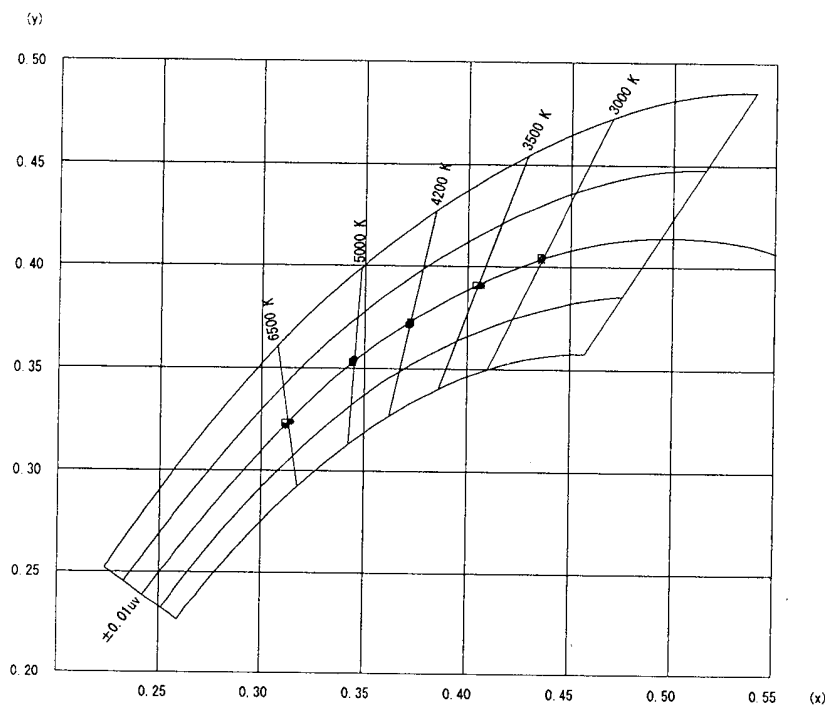

図 2 色温度再現測定結果

\section{4 実験用照明装置の特性のまとめ}

この模型において、調色照明器具は各単色光点灯時の $\mathrm{x} \cdot \mathrm{y}$ 値を頂 点とした三角形で囲まれた範囲が調色可能範囲であり、色温度 $3000 \mathrm{~K}$ から $6500 \mathrm{~K}$ の黒体軌跡に沿った再現が可能であることが明 らかとなった。この色温度の範囲で 2001x から 3500lx の範囲で調光 ぶ可能である。今回の測定で本照明器具は、今回の模型実験を行う 二めに必要な照度・色温度再現性を充分に満たしていると言える。

\section{3. 実験概要}

実験には図3・表2に示す模型を用いた。模型は中村らの実験3をを参 涪ニ、1/10スケール $(420 \mathrm{~mm} \times 420 \mathrm{~mm} \times 240 \mathrm{~mm})$ の室内模型とした。基 焦空間と評価空間の模型は並べて設置した。評価空閒の模型にはそ 代え゙れ、居間、食堂、または個室を想定した家具を配置したもので だ：模型内部の内装は全て白で統一した。また、模型内部の正面 $\cdots * 5$ 色（青、緑、黄、赤、紫）の紙 $(75 \mathrm{~mm} \times 45 \mathrm{~mm})$ を貼り、色の 兒关の然さを評価する際の判断材料とした。表了に実験に用いた紙

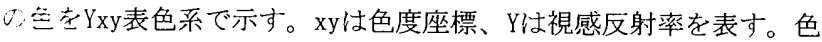
の胃には、MINOLTA COLOR READER（CR-13）を用いた。模型の天井 面べ央に直径 $70 \mathrm{~mm}$ の穴を開けてあり、そこから照明光が入る。基 隻空間の照明は中村らの実験 ${ }^{5}$ を参考に、色温度 $4200 K$, 床面照度 
2001xに設定した。評価空間の照明は床面照度5種類 (501x， 1001x， $2001 \mathrm{x}, 4001 \mathrm{x}, 8001 \mathrm{x}) \times$ 色温度 5 種類 $(3000 \mathrm{~K}, 3500 \mathrm{~K}, 4200 \mathrm{~K}, 5000 \mathrm{~K}$, 6500K)の25通りの組合せである。

評価項目は「好ましさ」に「明るさ」がどのように関係している かを調べるため、想定した行為の場としての雰囲気の「好ましさ」 と「明るさ」を設定した。また、照明の色温度によって色が不自然 に見えると不快が生じると考えられるため、上記の 2 項目に「色の見 えの自然さ」を加えた計3項目について評価を得た。それぞれの項目 を「好ましい一好ましくない」「明るい一暗い」「自然な一不自然 な」の7段階尺度のSD法で評価させた。被験者は20代の建築系学生男 女8名（男性3名、女性5名）である。
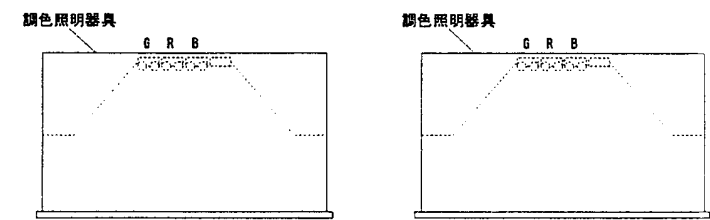

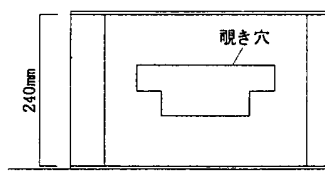

基淮空間

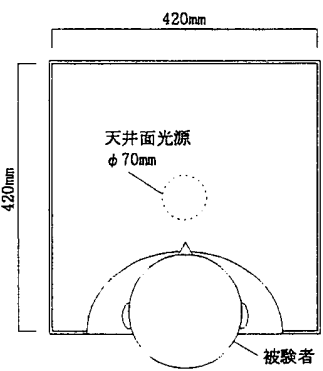

図 3 実験装置概要

実験手順として、被験者にはまず基準空間（4200K, 2001x）に順応 した後、すぐ横にある評価空間を10秒見てもらい、見終わったあと に評価空間の評価を記入してもらった。その後基準空間を30秒見て もらい次の評価対象を同様に評価してもらった。この評価をひとつ
の空間に対し25回繰り返した。まず、居間の模型で「くつろぎの場」 「だんらんの場」を想定した実験をおこない、次に食堂の模型で「食 べる場」「作る場」を、最後に個室の模型で「学びの場」「おやす みの場」の実験をおこなった。なお「作る場」での想定行為は料理 を、「おやすみの場」は就寝前の寝室を想定するように指示した。 想定している行為は滞在型のものであるが，本研究ではその空間に 入って行く際に形成される照明環境の印象が最も強いと考えて, 上 記の手順を採用した。

表3 模型使用色一覧

\begin{tabular}{|c|c|c|c|c|c|c|}
\hline & \multicolumn{3}{|c|}{ CIE表色系 } & \multicolumn{3}{c|}{ マンセル表色系 } \\
\hline 色 & $\mathrm{Y}$ & $\mathrm{x}$ & $\mathrm{y}$ & $\mathrm{H}$ & $\mathrm{V}$ & $\mathrm{C}$ \\
\hline 百 & 85.20 & 0.314 & 0.328 & $8 \mathrm{PR}$ & 9.30 & 0.27 \\
\hline 青 & 18.62 & 0.195 & 0.240 & $7.4 \mathrm{~B}$ & 4.84 & 9.12 \\
\hline 緑 & 22.30 & 0.271 & 0.427 & $4.8 \mathrm{G}$ & 5.24 & 7.22 \\
\hline 黄 & 68.20 & 0.425 & 0.452 & $6 \mathrm{Y}$ & 8.52 & 9.52 \\
\hline 赤 & 17.80 & 0.503 & 0.297 & $2.8 \mathrm{R}$ & 4.80 & 13.73 \\
\hline 紫 & 14.50 & 0.345 & 0.247 & $3.4 \mathrm{PR}$ & 4.34 & 8.66 \\
\hline
\end{tabular}

\section{4. 実験結果・考察}

\section{1 色温度・照度と好ましさの関係}

7段階尺度を間隔尺度とみなしてー3〜3の得点を与え、全被験者の 評価の平均・分散を算出した。全被験者の評価の $80 \%$ が分散 2.0 以下 で正規分布とみなせることから、平均値により傾向を読み取ること ができると判断した。「食べる場」「作る場」「学ぶ場」では被験 者間の評価のばらつきは概ね小さかったが、他の 3 つの場において は被験者間でばらつきの見られる評価対象があった。これについて は考察中で述べる。

各行為の場としての好ましさを全被験者の平均值を用いて Kruithofおよび中村らの結果と比較したものを図4〜図9に示す。各 ○印の大きさは評価得点を0.5刻みに区切っている。○印のサイズが 大きい程好ましいことを示しており、白抜きのエリアはKruithofの 快適領域、ハッチングは不快領域を示す。Kruithofの実験では快適 さの判断の基準となる行為は明らかではない。また、中村らと行為 が共通している図4と図5は、実線の○印で今回の結果を、破線の○ 印で中村らの結果を重ね合わせて表している。中村らの実験においい

表2 実験設定条件一覧

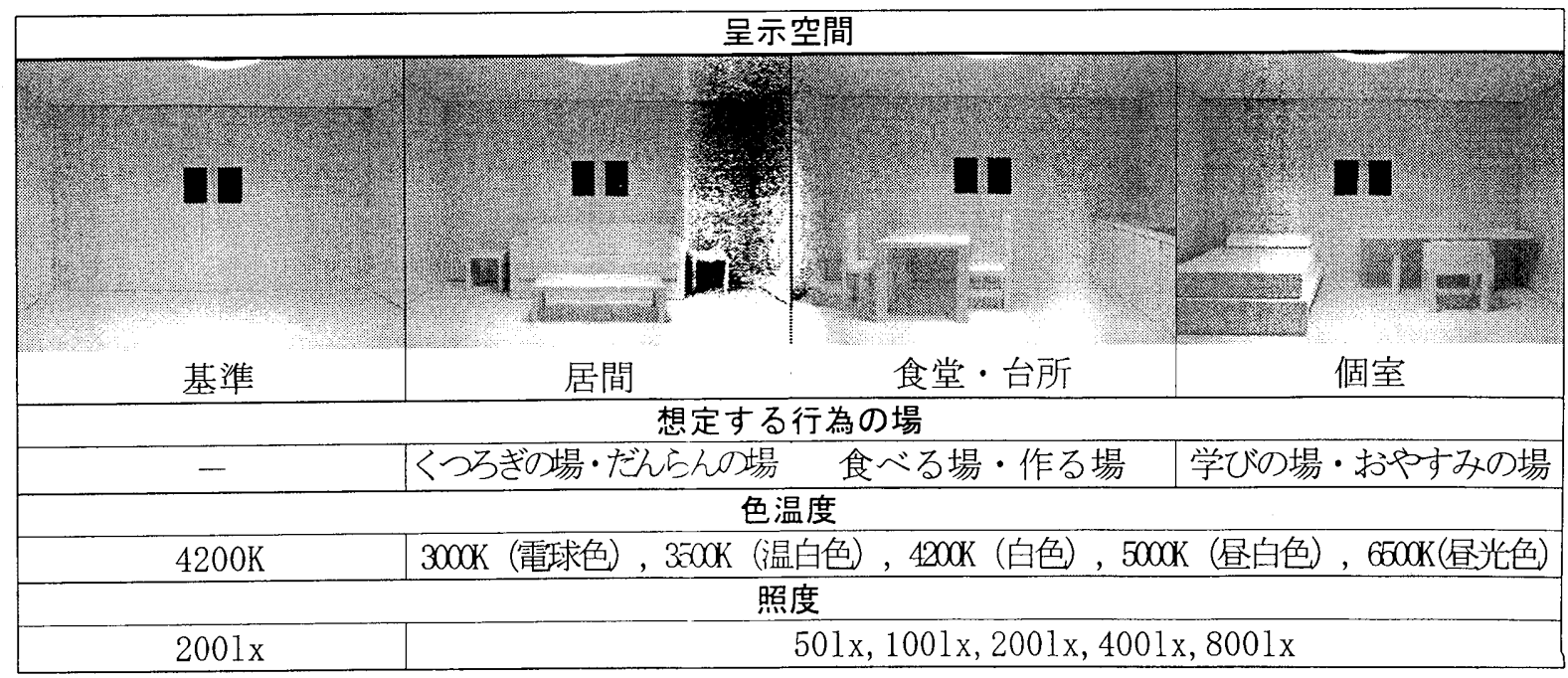


て設定された色温度は、若干本寒験の設定した色温度と異なるため、 ○印がずれているところもある。

以下にそれぞれの想定行為における結果について、好ましさの評 価の大きな方から 3 目までの○印を「好ましい」側、小さい方か ら3つ目までの○印を「好ましくない側と区分して考察する。

図4の「くつろぎの場」の評価においては、Kruithofの結果とやや 異なる傾向が見られ、全体的に低色温度の方が好まれる照度範囲が 広い。ただし低照度においてはばらつきが大きくなる傾向が見られ た。色温度による評価のばらつきの違いは見られない。

この結果はKruithofよりも中村らの実験結果に近く、模型実験と実 大実験で類似の傾向が見られたといえる。本実験では3500K, 8001xは 好ましいと評価されたが、中村らの実験では3900K以下における 8001xでの評価はおこなわれていないため比較することができない。

図5の「だんらんの場」の評価は、同じ居間空間でも「くつろぎの 場」よりもKruithofの結果に近いように見える。ただし、本実験で は3000Kでも6500Kでも2001x以上であれば好ましい側の結果となっ ており、この点はKruithofの結果と異なる。むしろ色温度に関わら ず、全体的に高めの照度が好まれる傾向にあると言える。「くつろ ぎの場」と異なり、低色温度において評価にばらつきが見られた。

「だんらん」という行為は「くつろぎ」と異なり他者の存在を示唆 することから，人の顔が自然に見えるかどうかということが考慮さ れている可能性があると考えられる。また、今回の結果では 5000K, 8001xは非常に好ましいとされており、8001xでは好ましさが 飽和または低下するという中村らと異なる結果となった。この違い については、だんらんとして想定された行為が被験者によって異な った可能もあると考えられる。

図6の「食べる場」はKruithofの結果と最も近い傾向となったが低 色温度高照度の不快領域は見られない。6500Kを除くと，2001x以上 なら概ね好ましい側とも言える。

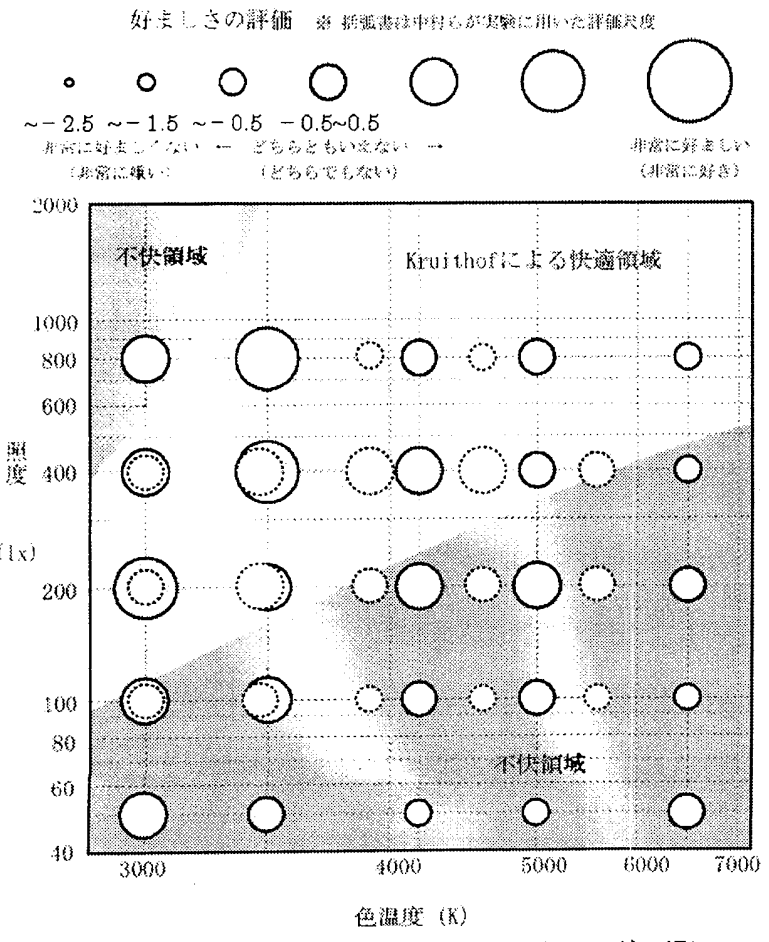

図 4 色温度・照度と好ましさの関係（くつろぎの場）

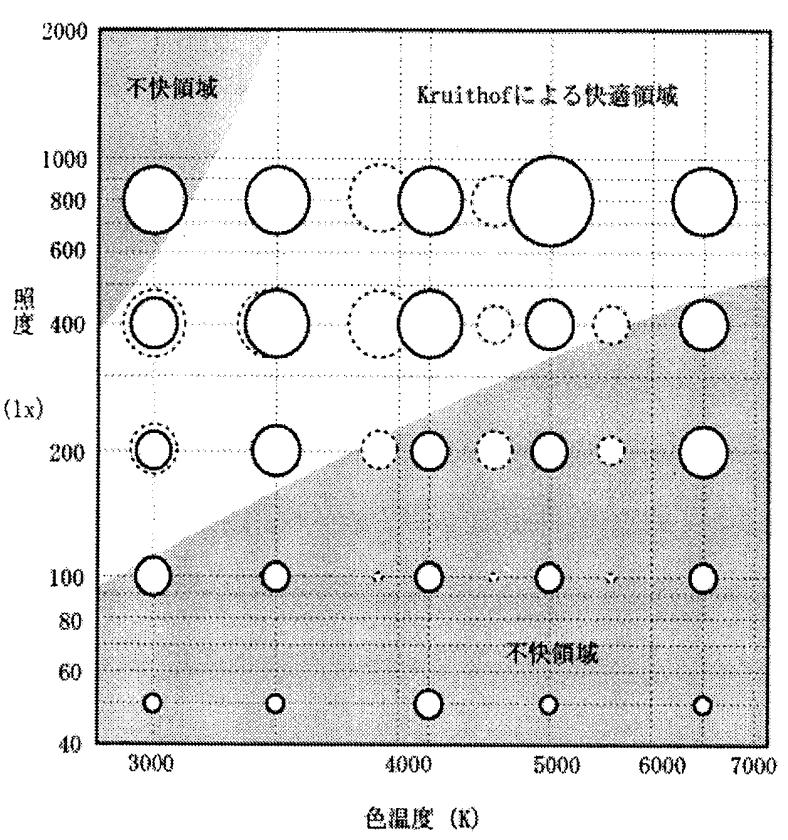

図 5 色温度・照度と好ましさの関係（だんらんの場）

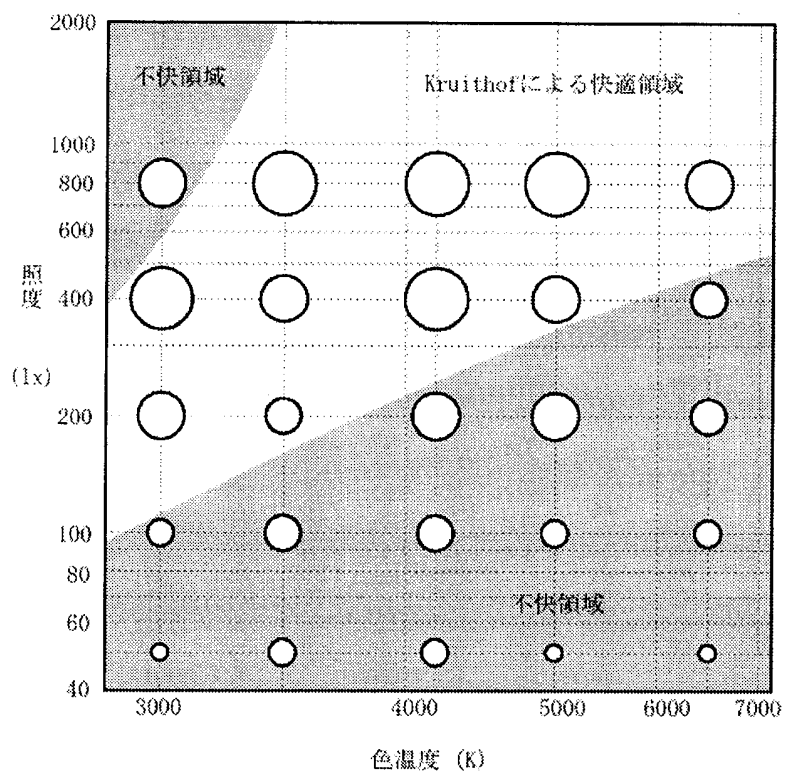

図 6 色温度・照度と好ましさの関係（食べる場）

図7の「作る場」はKruithofの快適領域内に好まれる組み合わせが 多、が、好まれる領域の傾向はかなり異なる結果となった。むしろ 3000Kを除いて高照度が好まれると言える。また、Kruithofの不快領 域であっても作る場としては高色温度で2001x以上なら比較的好ま こニ上されることが分かった。

区8の「学びの場」は「作る場」に似ており、高色温度で高照度が 立礼る傾向にある。行為としては，作業環境という共通点がある こ䒓えられる。低色温度においては「作る場」よりも、若千好まし 、害りの評価となっている。

区9の「おやすみの場」はKruithofの結果と全く異なっている。全 体:低照度であるほど好ましいとされる。中でも、低色温度が好ま れていることから、「おやすみの場」については更に低色温度・低 照度におおける検証が必要だと考えられる。 


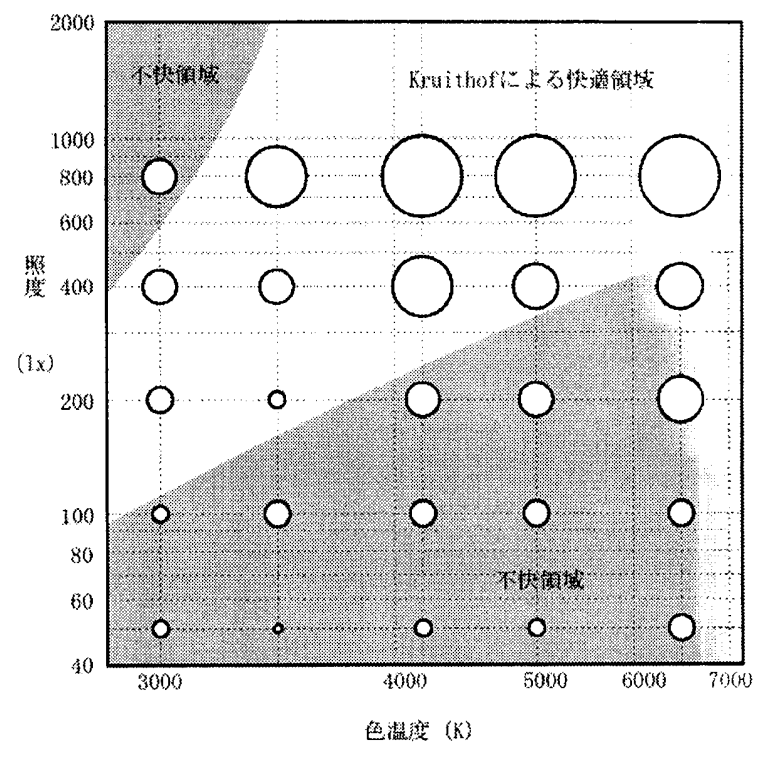

図 7 色温度・照度と好ましさの関係（作る場）

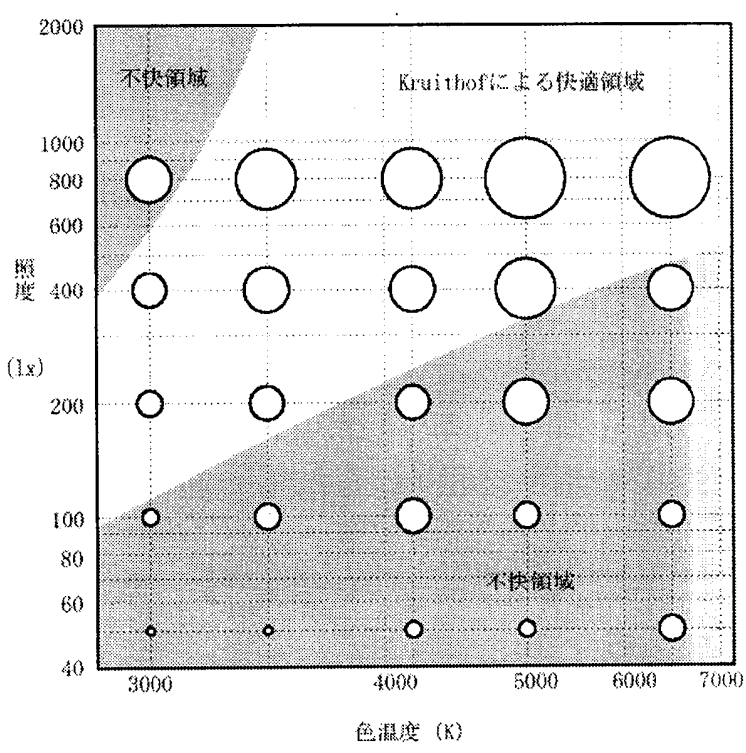

図 8 色温度・照度と好ましさの関係（学びの場）

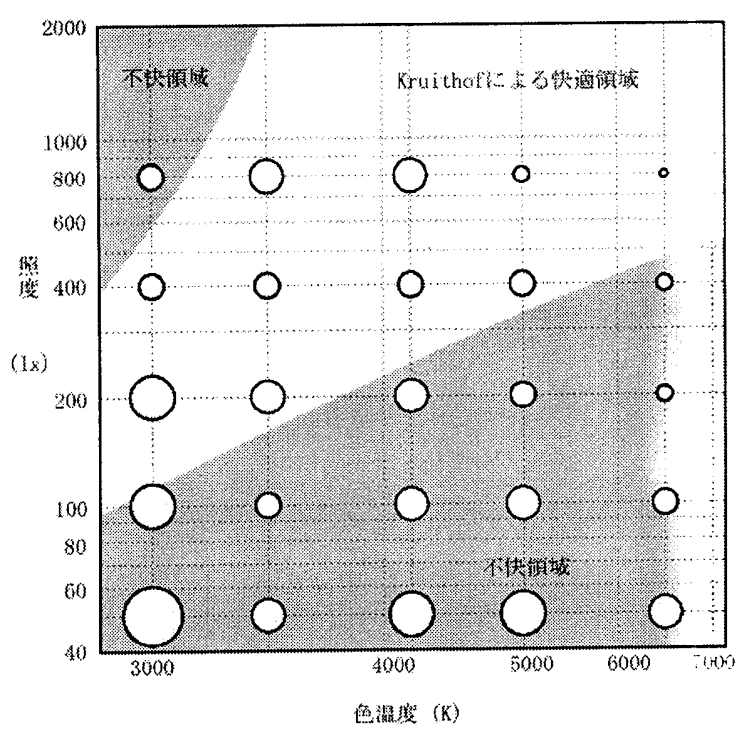

図 9 色温度・照度と好ましさの関係（おやすみの場）

\section{$4.23 つ$ 3評価尺度の相関}

色の見えの自然さは、行為ごとでは無く、部屋ごとに評価しても らったため、照度・色温度の変化によって評価されたものだと考え られる。しかし、「好ましさ」と「色の見えの自然さ」と明るさ」 の関係を見ることで、行為ごとに求められる照明環境について説明 できることがあると考える。想定行為ごとに3つの評価尺度の相関に ついて調べた。表4に尺度間の相関を示す。

表4を見ると多くの場合に相関が見られるが、好ましさと明るさの 相関は全体に高く、これと比べると好ましさと色の見えの自然さの 相関はやや低い。明るさと色の見えの自然さの間にはどの想定行為 においてもある程度の相関があり、その值はどれも同じようである。 今回の条件では特に色の見えが不自然なものはなかったため、明る さの違いによる色の見えの差異が評価されたものと考えられる。以 下に、「好ましさ一明るさ」の相関について行為ごとに述べる。

「くつろぎの場」では、好ましさと明るさにほとんど相関が見ら れない。明るいかどうかよりも、くつろげるための雲囲気かどうか が好ましさの判断基準となっていると考えられる。

「だんらんの場」では、「くつろぎの場」と比べて好ましさと明 るさの相関が高い。同じ居間空間でも人の顔や表情がよく見えるよ うに明るさや色の見えの自然さが求められていると考えられる。

「食べる場」では、好ましさと明るさの相関が高い。「だんらん の場」と同様、他者との関係において食卓では明るい䨌囲気が求め られると考えられる。

「作る場」においても、好ましさと明るさの相関が高い。こちら は作業を伴うことから、明るいことが重要なのだと考えられる。

「学びの場」では、好ましさと明るさに相関がある。「作る場」 と同様、明るさが重要で、好ましさの評価を上げていると言える。

「おやすみの場」では、好ましさと明るさに負の相関があると言 える。暗いほど好ましさの評価が上がり、落ち着きを感じさせる照 明環境が好ましいとされるということを表している。この「低色温 度の光は照度が上がっても好ましい」という結果は、低色温度の光 は人間の生体リズムに影響しないとされている事と結び付く結果で あり、大変興味深い。

全体の傾向を見ると「だんらんの場」「食べる場」「作る場」「学 びの場」の $4 つ の$ 想定行為には同じような相関が見られ、「くつろ ぎの場」と「おやすみの場」は他と違う傾向が見られる。この2つの 行為を想定する場を作る際には、「明るさ」や「色の見えの自然さ」 について他とは異なる考え方をすべきであると考えられる。

照度別・色温度別に尺度間の相関係数を算出した比較も試みたが、 特徵や傾向は見られなかった。

\section{表 4 評価尺度間の相関}

\begin{tabular}{|c|c|c|c|}
\hline & 好ましさー明るさ & 好ましさ一色の見えの自然さ & 明るさ一色の見えの自然さ \\
\hline くつろきの埸 & 0.2086 & 0.0740 & 0.5113 \\
\hline だんらんの埸 & 0.7716 & 0.3694 & 0.4316 \\
\hline 食べる場 & 0.7151 & 0.4315 & 0.5724 \\
\hline 作る谒 & 0.8845 & 0.5791 & 0.5430 \\
\hline 学ひの堨 & 0.7691 & 0.5095 & 0.6062 \\
\hline おやすみの場 & -0.5047 & -0.4027 & 0.5743 \\
\hline
\end{tabular}

5. まとめ

実験の結果から、生活行為によって好ましいとされる照度および 
色温度が異なることが確認できた。また、Kruithofの快適領域は想 定行為によってよく当てはまるものと、一部当てはまらないものが あるという結果を得た。

結果が比較的当てはまるものには「だんらんの場」と「食べる場」 の 2 つの想定行為があった。結果が一部当てはまらないものには4つ の想定行為があった。「おやすみの場」については、低色温度が好 まれることが異なり、「作る場」「学びの場」では、高照度が優先 で、より低色温度は好まれないことが異なった。「くつろぎの場」 では、低色温度が好まれることが異なったが、これは中村らの実空 間実験とは類似している。また、色温度が高くなると好まれる照度 範囲が限られる事も確認できた。このことより、Kruithofの快適領 域について、比較的リラックスした状態の行為を想定する場合には 再検討する必要があることが分かった。

評価尺度間の相関とも合わせて考えると，行為により場に求めら れる照度と色温度の組み合わせが異なる要因としては, まず要求さ れる視作業により求められる明るさの影響が最も大きいと言える。 同じ空間で行為をともにする他者を見分けることも視作業と考えて よさそうだが，行為によっては明るくないことが求められる場合も ある。色温度は明るさと比べれば影響力は小さいが, 視作業の種類 によって好まれる色温度が異なるように見える。物を相手に行う作 業では高めの色温度が好まれ，低い色温度は好まれないのに対し， リラックスした状態で他者と行為をともにする場合にはあまり色温 度が高くない方が好まるのではないだろうか。

今回の結果は蛍光ランプー種類の調光・調色により照度・色温度 の組み合わせと好ましさの関倸を調べたものであるが，ランプの種 類や演色性の違いにより明るさ感や空間の見えが異なることも考え られるので, 照度と色温度だけでなく, 明るさ知覚による表現など も含め，行為の区分とともに今後検討していくことが必要であろう。

\section{謝辞}

本実験の実施には富松奈々氏（九州芸術工科大学大学院卒業生）の協力を頂 いた。また野口公喜氏（松下電工株式会社）には調光照明装置についてアドバ イスを頂いた。ここに謝意を表する。本研究は一部文部科学省 21 世紀COEプロ グラム「感覚特性に基づく人工環境デザイン研究拠点」の補助を受けた。

\section{类考文献}

1) A. A. Krui thof : Tubular Luminescence Lamps for General Il lumination, Philips Technical Review 6, pp.65-96, 1941

2）中村 肇：Kruithof（クルイトフ）のカーブは正しいか?，照明学会 誌, 85-9, pp. 793-795, 2001.9

3）石橋 淳一ほか：照度・色温度、気温、周用色彩が人間心理に及ぼす影響, 日本建築学会大会学術梗概集, D-1, pp. 347-345, 2001.9

4）武田 紀子ほか：照明方式と照度・色温度の組み合わせ条件が心理反応に 及ぼ寸影響, 日本建築学会大会学術梗概集, D-1, pp. 421-422, 2002.8

5）中村 肇ほか：照度 ·色温度と雾囲気の好ましさの関係, 照明学会 誌, 81-8A, pp. 687-694, 1997.8

6) 久保田 真由ほか: 行為と照度 -色温度の快適範讲に関する研究, 照明学 会第37回全国大会, pp. 148-149，2004.8

7）望月 悦子ほか：空間共有者と照明方式が快適照明条件に与える影響に関 する主䚒評価実験，照明学会第36回全国大会，p. $90 ， 2003.8$

8）石原 従道ほか：縮尺模型を用いた居間における照明の心理的効果に関す る研究, 日本建築学会大会学術梗概集, D-1, pp. 325-326, 1996.9

9）大尚行ほか：RGB蛍光ランプを用いた模型実験用照明装置の照度色温 贯等性, 照明学会第37回全国大会, 2004.8

10)匹田 光男 : 照明認識視空間の概念に基づく空間の明るさ, 照明学会誌, $56-10$, pp. $754-758,2002.10$

（2006年 7 月 10 日原稿受理， 2006 年12月 27 日採用決定） 